\title{
10. CRUSTAL STRUCTURE OF THE JAPAN TRENCH: THE EFFECT OF SUBDUCTION OF OCEAN CRUST
}

\author{
Sandanori Murauchi, Department of Earth Sciences, Chiba University, Chiba, Japan \\ and \\ William J. Ludwig, Lamont-Doherty Geological Observatory of Columbia University, Palisades, New York
}

\begin{abstract}
Evaluation and synthesis of seismic-refraction measurements made in the Japan trench in the light of the results of deep-sea drilling from Glomar Challenger Legs 56 and 57 result in a schematic section of the crustal structure. The Pacific Ocean crustal plate underthrusts the leading edge of the continental block of Northeast Japan at a low angle and follows at depth the upper seismic belt of the Wadati-Benioff zone. Overthrust continental crust extends to within $30 \mathrm{~km}$ of the trench axis; thenceforward the lower inner trench slope is formed by a thick, wedge-shaped body of low-velocity sediments. The volume of these sediments is too small to represent all the sediments scraped off the Pacific plate and transported from land. This indicates that substantial amounts of sediment are carried down along slip planes between the continental block and the descending plate. Dewatering of the sediments lubricates the slip planes. The slip planes migrate upward into the overlying continental edge, causing removal of material from its base. This tectonic erosion causes subsidence and landward retreat of the continental edge.
\end{abstract}

\section{INTRODUCTION}

In terms of plate tectonics, the convergence of two crustal plates may result in underthrusting (subduction) of one plate beneath the other. The process generally envisioned for seismically active island arcs, marked by a deep-sea trench, is that the sediments on the descending oceanic plate are either scraped off and thrust against (accreted to) the edge of the margin or dragged beneath it. As the subducted plate reaches depths where partial melting occurs, some molten material rises to form the volcanoes of the island arc.

The Japan arc-trench system off the Sanriku district of northeastern Honshu is one of the most intensively studied convergent margins of the world. Ludwig et al. (1966) demonstrated that the continental crust of Japan in the Sanriku district continues to within $70 \mathrm{~km}$ of the trench axis, that the lower inner trench slope is composed of a thick wedge of low-velocity sediments, and that the outer trench slope has normal-antithetic faults, presumably caused by tensional forces exerted in the convex side of a descending crustal plate. These observations, which helped form the basis of plate-tectonic theory, have since been substantiated and extended greatly by detailed seismic surveys of the Hydrographic Office of the Japan Maritime Safety Agency and the Geological Survey of Japan.

In preparation for drilling a transect of holes across the Japan Trench, intensive single-channel seismicreflection surveys were carried out by Chiba University and the Ocean Research Institute of Tokyo University between 39 and $40^{\circ} \mathrm{N}$. Lines of multichannel seismicreflection measurements were made by JAPEX to select the prime drill sites (see foldouts, back cover, this volume, Part 1; Nasu et al., 1979). During Legs 56 and 57, the Glomar Challenger drilled holes at seven locations in the Japan Trench. This report combines twoship seismic-refraction data obtained by us under the U.S.-Japan Cooperative Science Program (Ludwig et al., 1966) with OBS refraction data obtained by the Research Group for Explosion Seismology in Japan (Yoshii and Asano, 1972; Asano, pers. comm.) and sonobuoy refraction data obtained by Chiba University in 1977 , as part of the IPOD site survey program (Murauchi et al., 1978), and in 1978 (Murauchi et al., 1979).

\section{RESULTS OF 1977 IPOD SITE SURVEY}

Single sonobuoy refraction profiles were recorded at six stations (Figure 1). Profiles were shot unreversed along lines with minimal sea floor relief. A Bolt 1500Ctype air gun of $4.91(300 \mathrm{cu}$. in.) capacity operated at a pressure of 80 to $90 \mathrm{~kg} / \mathrm{cm}^{2}$ was used as the sound source.

The velocity-depth information from the short-range sonobuoy measurements (Table 1) and that obtained earlier from two-ship measurements are shown in the schematic structure section of Figure 2. Because sonobuoy measurements have better resolution in shallower layers than the two-ship measurements, the sonobuoy solutions were used to define the upper layers with velocities less than $4.3 \mathrm{~km} / \mathrm{s}$, as shown by dashed lines in Figure 2. Sonobuoy profile J-la, single-channel 


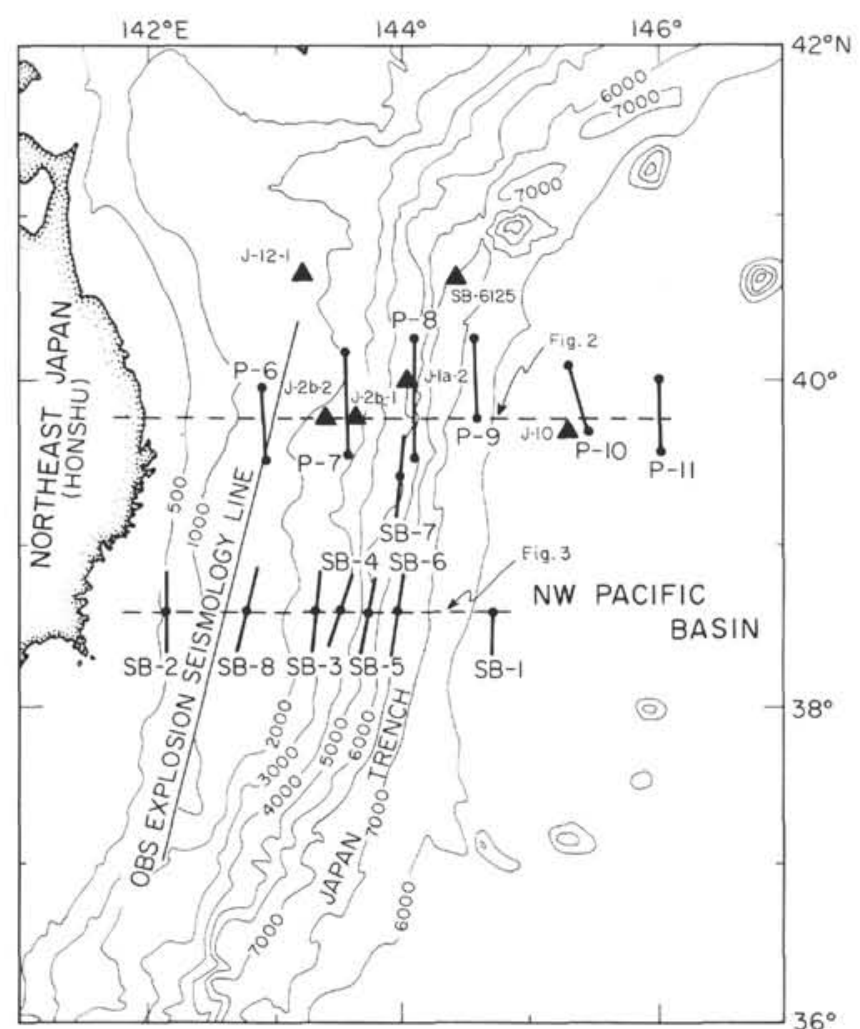

Figure 1. Location of seismic-refraction profiles and lines of sections. Isobaths in meters.

seismic-reflection profiles (Murauchi et al., 1978) and JAPEX multichannel seismic-reflection profiles of the lower inner trench slope confirm that it is underlain by a thick prism of relatively low seismic velocity, typical of semiconsolidated to consolidated sediment. The sediments appear to lie directly over the descending oceanic crust (layer 2), which can be followed confidently from the outer trench slope below the inner trench slope (Nasu et al., 1979). Reflections from within the sedimentary prism can be traced as continuous events only over relatively short distances.

Drilling at Sites 434 and 441 did not penetrate the sediments to basement beneath the lower inner trench slope. The boreholes bottomed in terrigenous slope deposits of upper Miocene to Pleistocene age. Presumably, oceanic sediments occur lower in the unsam- pled section. Drilling at Site 438 and 439 near the trench-slope break, $90 \mathrm{~km}$ from the trench axis, also recovered Miocene-Pleistocene terrigenous slope deposits. These sediments overlie Oligocene sandstones, which in turn overlie a boulder conglomerate unconformably overlying a silicified claystone of Upper Cretaceous age. This Cretaceous suite of rocks (velocity near $4.3 \mathrm{~km} / \mathrm{s}$ ) is interpreted as a southern extension of the metamorphic belts of Hokkaido (Moore and Fujioka, this volume). Recovery of boulders of intermediate igneous rocks at Site 439 led the Leg 57 Scientific Staff (1978) to infer that volcanic intrusives with continental affinities outcropped just to the east of Site 439 during the Oligocene but have since subsided.

Extrapolation of the borehole results from seismicreflection records suggests that the continental crust may extend to within $30 \mathrm{~km}$ of the trench axis. Certainly, the volume of sediments beneath the lower inner trench slope is not great enough to have accommodated all the sediments scraped off the Pacific Plate in the Neogene at the present rate of convergence of the plate with Japan (von Huene et al., this volume). Therefore, substantial amounts of sediments must be subducted with the oceanic plate with no net accumulation of sediments on the lower inner trench slope. An alternative explanation is that continuous tectonic erosion of accreted oceanic sediments, terrigenous sediments, and continental crust occurs because of the subduction process, causing a landward retreat of the leading edge of the continental margin (Kulm et al., 1977). The leading edge of the continental block lies somewhere between profiles P-7 and P-8.

\section{RESULTS OF 1978 SONOBUOY SURVEY}

Several sonobuoy seismic-refraction profiles were made south of the IPOD transect along long. $38^{\circ} 35^{\prime} \mathrm{N}$ (Figure 1). The velocity-depth solutions from the sonobuoys (Murauchi et al., 1979) are listed in Table 2 and shown in the schematic structure section of Figure 3. An L-DGO-type 0.41 ( 25 cu. in.) air gun was used as the sound source at short distances, and small charges of explosives were used at the longer distances. Except for SB-1, which is a single, unreversed profile, all profiles were shot in opposite directions from a sonobuoy to form a pair of profiles akin to a split profile. Because of drift of the sonobuoy due to surface currents, refracted

TABLE 1

Results of Sonobuoy Measurements in the Japan Trench along Latitude $39^{\circ} 45^{\prime} \mathrm{N}$

\begin{tabular}{|c|c|c|c|c|c|c|c|c|c|c|c|c|}
\hline \multirow[b]{2}{*}{ Sonobuoy } & \multirow[b]{2}{*}{ Water } & \multicolumn{4}{|c|}{$\begin{array}{c}\text { Thickness } \\
(\mathrm{km})\end{array}$} & \multicolumn{5}{|c|}{$\begin{array}{c}\text { Velocity } \\
(\mathrm{km} / \mathrm{s})\end{array}$} & \multirow[b]{2}{*}{ Latitude (N) } & \multirow[b]{2}{*}{ Longitude (E) } \\
\hline & & $h_{2}$ & $h_{3}$ & $h_{4}$ & $h_{5}$ & $V_{2}$ & $V_{3}$ & $V_{4}$ & $V_{5}$ & $V_{6}$ & & \\
\hline$J-2 b-1$ & 2.20 & 1.20 & 0.42 & 0.68 & 1.41 & 1.7 & 2.0 & 2.8 & 4.7 & 5.6 & $39^{\circ} 46^{\prime}$ & $143^{\circ} 34^{\prime}$ \\
\hline $\mathrm{J}-2 \mathrm{~b}-2$ & 2.15 & 0.80 & 0.73 & 0.43 & 2.25 & 1.7 & 1.9 & 2.5 & 4.5 & 5.0 & $39^{\circ} 46^{\prime}$ & $143^{\circ} 22^{\prime}$ \\
\hline $\mathrm{J}-10^{\prime}$ & 5.35 & 0.65 & 0.45 & 1.19 & - & 2.0 & 4.9 & 5.5 & 6.9 & - & $39^{\circ} 40^{\prime}$ & $145^{\circ} 18^{\prime}$ \\
\hline $\mathrm{J}-12-1$ & 1.50 & 0.40 & 0.80 & 0.46 & 0.16 & 1.5 & 2.25 & 2.34 & 2.8 & 4.3 & $40^{\circ} 40^{\prime}$ & $143^{\circ} 15^{\prime}$ \\
\hline $\mathrm{J}-1 \mathrm{a}-2$ & 5.00 & 0.97 & 1.66 & - & - & $2.0^{*}$ & 3.0 & 5.0 & - & - & $39^{\circ} 59^{\prime}$ & $144^{\circ} 06^{\prime}$ \\
\hline SB-6125 & 6.93 & 1.94 & - & - & - & 2.5 & - & - & - & - & $40^{\circ} 38^{\prime}$ & $144^{\circ} 27^{\prime}$ \\
\hline
\end{tabular}

Notes: All sonobuoy refraction profiles are unreversed and were computed assuming that the layers are parallel. Asterisks indicate that the velocity is assumed. 


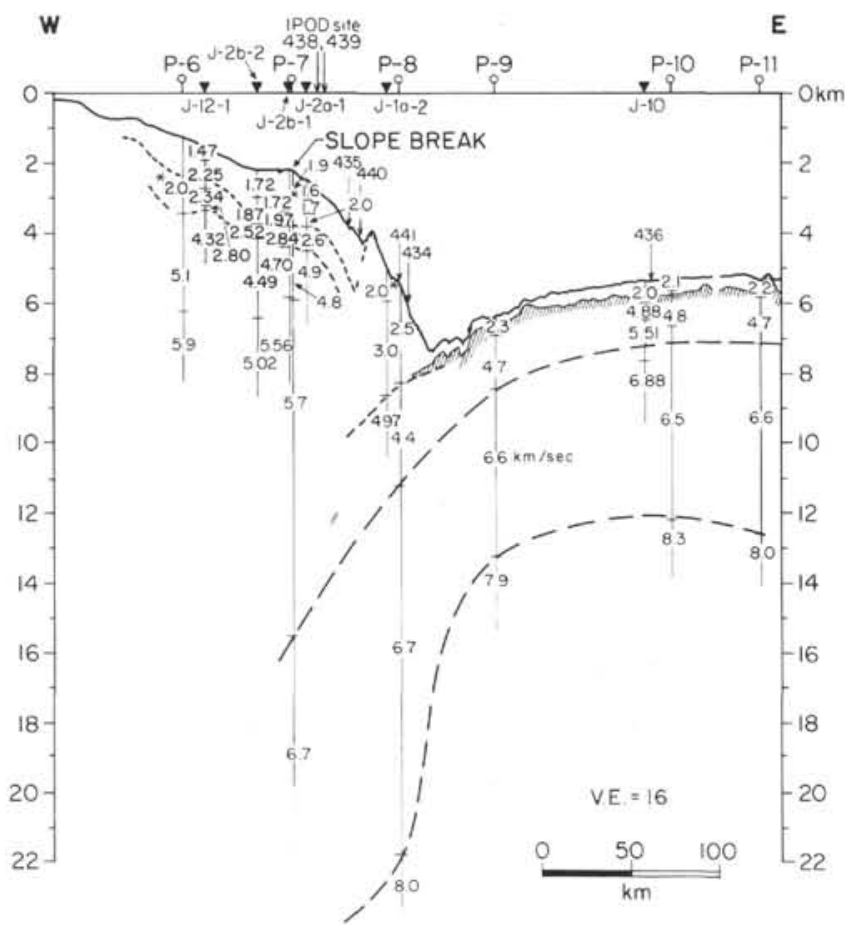

Figure 2. Velocity structure section of the Japan trench along lat. $39^{\circ} 45^{\prime} \mathrm{N}$, compiled from the data of Murauchi et al. (1978) and Ludwig et al. (1966).

arrivals from each pair of profiles did not align onto straight line segments having a common intercept on the time-distance record. Hence the data from each shot line of a profile pair were treated as a single, unreversed profile; the averages of the velocity and the depth determined in each direction were used to approximate the true values.

The velocity-depth section from the sonobuoy solutions (Figure 3) is similar to that of Figure 2. Sediments of velocity 1.6 to $3.1 \mathrm{~km} / \mathrm{s}$ of probable Oligocene-Pleistocene age overlie 3.6 to $5.1 \mathrm{~km} / \mathrm{s}$ (Upper Cretaceous?) material, which in turn overlies 5.8 to $6.2 \mathrm{~km} / \mathrm{s}$ continental crust. Sonobuoy station 5 demonstrates that continental crust extends to within $30 \mathrm{~km}$ of the trench axis. As to the north, the lower inner trench slope at $39^{\circ} 35^{\prime} \mathrm{N}$ is underlain by thick low-velocity sediments on a landward-plunging section of oceanic crust.

\section{RESULTS OF GEOMAGNETIC SURVEY}

Using geomagnetic data collected by many Japanese and U. S. institutions, Murauchi et al. (1973), among others, constructed total-intensity magnetic-anomaly profiles for the northwest Pacific off Hokkaido and Northeast Japan. The magnetic-anomaly patterns continue from the ocean basin beneath the lower inner trench slope, concomitant with a gradual decrease in amplitude landward from the trench. This decrease in magnetic-anomaly amplitude is probably caused by the increased distance to the magnetic source. On the lower inner trench slope between $38^{\circ} 30^{\prime} \mathrm{N}$ and $39^{\circ} 10^{\prime} \mathrm{N}$, this pattern of magnetic anomalies is confirmed by the dense magnetic observations of Matsuzaki (1959). The magnetic anomalies can be traced $50 \mathrm{~km}$ landward from the trench axis with no appreciable change in wavelength, indicating that the Pacific plate extends under the inner trench slope and is not greatly disturbed up to at least 50 $\mathrm{km}$ from the trench axis.

\section{RE-ANALYSIS OF TWO-SHIP SEISMIC-REFRACTION DATA}

Because all the data strongly suggest that oceanic crust underlies the lower inner slope of the Japan Trench, we re-examined the time-distance graphs produced from the two-ship seismic-refraction measurements of Ludwig et al. (1966). Profiles 7 and 8 were originally interpreted to show the depth of the M-discontinuity increasing from $12 \mathrm{~km}$ below the outer trench slope to $26 \mathrm{~km}$ below the trench-slope break (Figure 2). Alternative velocity-depth solutions of the refraction travel-time data, compatible with the conceptual model of underthrusting Pacific plate beneath the island arc, are listed in Table 3 and shown in Figure 4.

\section{COMPOSITE SEISMIC-STRUCTURE SECTION AT LATITUDE $39^{\circ} 40^{\prime} \mathrm{N}$}

Long-baseline refraction measurements made on land and at sea by the Research Group for Explosion Seismology in Japan (Yoshii and Asano, 1972; Asano, pers. comm.), two-ship refraction measurements, and sonobuoy refraction measurements are used to construct the structure section of Figure 4. From the section, it can be concluded, first, that under the inner trench slope the crustal layers are gently warped, essentially conformable to the sea-floor topography.

TABLE 2

Results of Sonobuoy Measurements in the Japan Trench along Latitude $38^{\circ} 35^{\prime} \mathrm{N}$

\begin{tabular}{|c|c|c|c|c|c|c|c|c|c|c|c|c|c|c|c|c|c|c|c|c|}
\hline \multirow[b]{2}{*}{ Sonobuoy } & \multirow[b]{2}{*}{ Water } & \multicolumn{8}{|c|}{$\begin{array}{c}\text { Thickness } \\
(\mathrm{km})\end{array}$} & \multicolumn{9}{|c|}{$\begin{array}{c}\text { Velocity } \\
(\mathrm{km} / \mathrm{s})\end{array}$} & \multirow[b]{2}{*}{ Latitude $(\mathrm{N})$} & \multirow[b]{2}{*}{ Longitude (E } \\
\hline & & $h_{2}$ & $h_{3}$ & $h_{4}$ & $h_{5}$ & $h_{6}$ & $h_{7}$ & $h_{8}$ & $h_{9}$ & $V_{2}$ & $v_{3}$ & $V_{4}$ & $V_{5}$ & $V_{6}$ & $v_{7}$ & $v_{8}$ & $v_{9}$ & $v_{10}$ & & \\
\hline SB-1 & 5.65 & 0.49 & 0.76 & 1.49 & 3.67 & - & - & - & - & 2.3 & 3.9 & 5.9 & 7.3 & 8.5 & - & - & - & - & $38^{\circ} 34^{\prime}$ & $144^{\circ} 41^{\prime}$ \\
\hline SB-2 & 0.33 & 0.74 & 0.34 & 0.60 & 0.93 & 1.39 & 1.21 & - & - & $1.55^{*}$ & 2.0 & 2.3 & 3.6 & 4.2 & 5.1 & 5.8 & - & - & $38^{\circ} 28^{\prime}$ & $142^{\circ} 06^{\prime}$ \\
\hline SB-3 & 2.34 & 0.53 & 0.29 & 0.61 & 0.90 & 2.53 & 2.00 & - & - & 1.7 & 2.3 & 2.6 & 4.1 & 4.7 & 6.0 & 7.3 & - & - & $38^{\circ} 31^{\prime}$ & $143^{\circ} 18^{\prime}$ \\
\hline SB-4 & 2.95 & 1.62 & 0.89 & 1.31 & - & - & - & - & - & 2.2 & 3.6 & 5.0 & 6.5 & - & - & - & - & - & $38^{\circ} 33^{\prime}$ & $143^{\circ} 33^{\prime}$ \\
\hline SB-5 & 5.33 & 0.86 & 0.71 & 0.67 & 1.74 & - & - & - & - & 1.7 & 3.1 & 4.3 & 4.7 & 6.2 & - & - & - & - & $38^{\circ} 33^{\circ}$ & $143^{\circ} 46^{\prime}$ \\
\hline SB-6 & 6.05 & 0.46 & 2.62 & 2.41 & - & - & - & - & - & 1.8 & 2.5 & 5.2 & 7.2 & - & - & - & - & - & $38^{\circ} 33^{\prime}$ & $143^{\circ} 57^{\circ}$ \\
\hline SB-7 & 4.73 & 5.00 & 1.46 & 2.62 & 1.60 & 1.06 & 1.02 & - & - & $2.0^{*}$ & 2.5 & 3.0 & 4.7 & 5.1 & 5.9 & 7.2 & - & - & $39^{\circ} 32^{\prime}$ & $144^{\circ} 00^{\prime}$ \\
\hline SB-8 & 1.45 & 0.21 & 0.38 & 0.48 & 0.17 & 0.87 & 0.09 & 1.50 & 1.93 & $1.55^{*}$ & 1.8 & 1.9 & 2.1 & 2.7 & 3.1 & 3.7 & 4.8 & 6.2 & $38^{\circ} 41^{\prime}$ & $142^{\circ} 49^{\prime}$ \\
\hline
\end{tabular}

*Velocity assumed. 


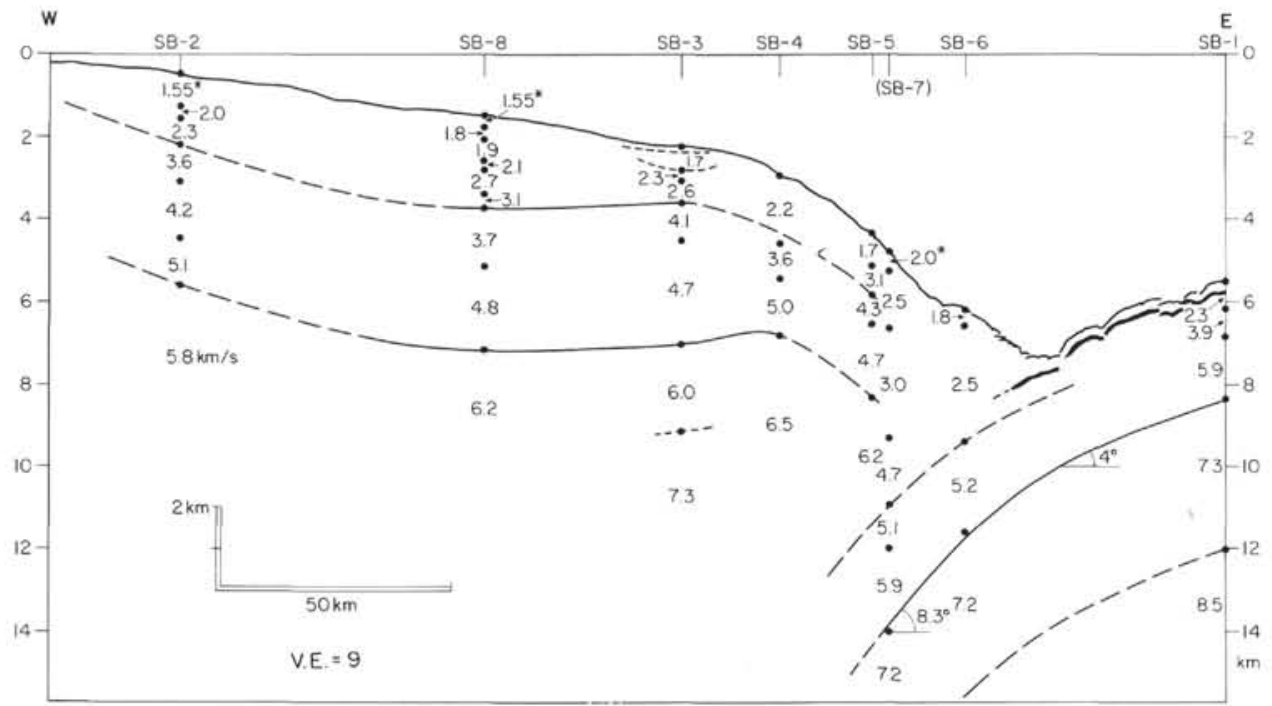

Figure 3. Velocity structure section of the Japan Trench along lat. $38^{\circ} 35^{\prime} \mathrm{N}$, after Murauchi et al. (1979).

TABLE 3

Alternative Interpretation of Two-Ship Refraction Profiles of Ludwig et al. (1966)

\begin{tabular}{|c|c|c|c|c|c|c|c|c|c|c|c|c|c|c|}
\hline \multirow[b]{2}{*}{ Profile } & \multirow[b]{2}{*}{ Water } & \multicolumn{5}{|c|}{$\begin{array}{l}\text { Thickness } \\
(\mathrm{km})\end{array}$} & \multicolumn{6}{|c|}{$\begin{array}{c}\text { Velocity } \\
(\mathrm{km} / \mathrm{s})\end{array}$} & \multirow[b]{2}{*}{ Latitude (N) } & \multirow[b]{2}{*}{ Longitude (E) } \\
\hline & & $h_{2}$ & $h_{3}$ & $h_{4}$ & $h_{5}$ & $h_{6}$ & $V_{2}$ & $V_{3}$ & $V_{4}$ & $V_{5}$ & $V_{6}$ & $V_{7}$ & & \\
\hline $6 \mathrm{~N}$ & 1.33 & 1.81 & 4.09 & 5.03 & - & - & $1.95 *$ & 5.05 & 5.91 & 7.18 & - & - & $39^{\circ} 58^{\prime}$ & $142^{\circ} 53^{\prime}$ \\
\hline $\mathrm{S}$ & 1.33 & 2.56 & 1.52 & 6.23 & - & - & - & - & - & - & - & - & $39^{\circ} 30^{\prime}$ & $142^{\circ} 56^{\prime}$ \\
\hline $7 \mathrm{~N}$ & 1.85 & 1.86 & 1.75 & 6.05 & 11.84 & 6.53 & 1.93 & 4.77 & 5.74 & 6.29 & 6.76 & 8.06 & $40^{\circ} 10^{\prime}$ & $143^{\circ} 33^{\prime}$ \\
\hline $\mathrm{S}$ & 2.75 & 1.71 & 1.90 & 2.75 & 7.79 & 7.59 & - & - & - & - & - & - & $39^{\circ} 31^{\prime}$ & $143^{\circ} 34^{\prime}$ \\
\hline $8 \mathrm{~N}$ & 4.74 & 3.06 & 4.63 & 6.05 & - & - & 2.49 & 4.42 & 6.74 & 7.59 & - & - & $40^{\circ} 15^{\prime}$ & $144^{\circ} 06^{\prime}$ \\
\hline $\mathrm{S}$ & 6.20 & 2.49 & 1.11 & 6.05 & - & - & - & - & - & - & - & - & $39^{\circ} 30^{\prime}$ & $144^{\circ} 07^{\prime}$ \\
\hline $9 \mathrm{~N}$ & 6.48 & 0.53 & 1.50 & 3.31 & - & - & 2.33 & 4.70 & 6.63 & 7.92 & - & - & $40^{\circ} 15^{\prime}$ & $144^{\circ} 35^{\prime}$ \\
\hline $\mathrm{S}$ & 6.48 & 0.53 & 1.66 & 4.67 & - & - & - & - & - & - & - & - & $39^{\circ} 47^{\prime}$ & $144^{\circ} 36^{\prime}$ \\
\hline
\end{tabular}

*Velocity assumed.

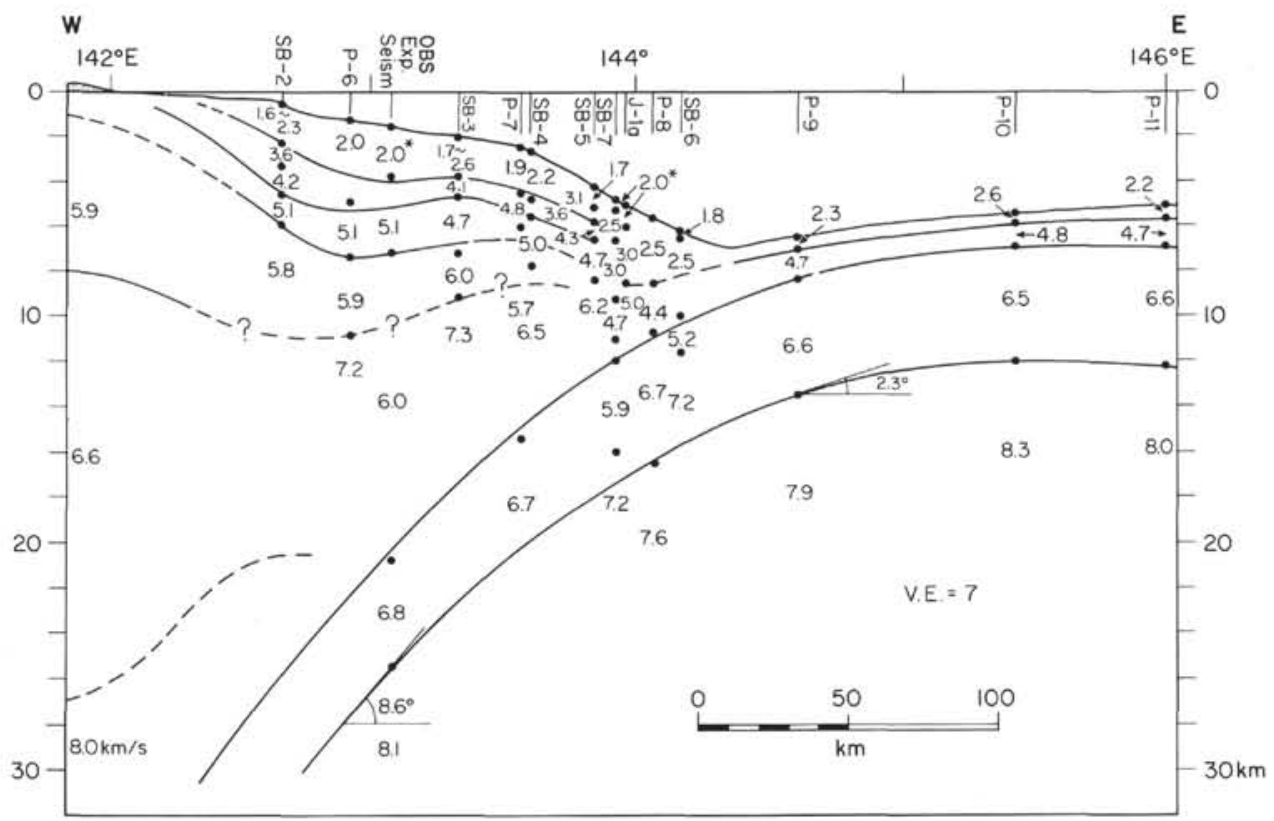

Figure 4. Composite velocity structure section of the Japan Trench along lat. $39^{\circ} 45^{\prime} \mathrm{N}$. Sources of data are given in the text. 
Second, the Pacific plate underthrusts the island-arc massif. A distinction must be made between the 8.0 $\mathrm{km} / \mathrm{s}$ mantle material underlying the mainland and the $8.1 \mathrm{~km} / \mathrm{s}$ interface beneath the continental slope, measured by the Research Group OBS refraction profile, which probably corresponds to the upper mantle of the descending Pacific plate. Similar low-angle thrusting of an oceanic plate beneath an island-arc system is seen off the Aleutians (Grow, 1973), Lesser Antilles (Westbrook, 1975), and Bonin Islands (Hotta, 1970).

Third the island-arc crust extends eastward to within $30 \mathrm{~km}$ of the trench axis. The sedimentary prism of the lower inner trench slope consists of layers having velocities of 1.8 to $3.0 \mathrm{~km} / \mathrm{s}$. There seems to be a discrepancy between the results of profiles SB-6 and two-ship profile $\mathrm{P}-8$, but this is probably because the profiles were not made at the same latitude. The velocities in the sedimentary prism are derived from refracted arrivals; a sonobuoy wide-angle reflection profile near the trench axis at $40^{\circ} 40^{\prime} \mathrm{N}$ latitude gave a $2.5 \mathrm{~km} / \mathrm{s}$ interval velocity for the sedimentary prism (Murauchi et al., 1978).

Finally, there is a problem in correlating the boundary between the $6.0 \mathrm{~km} / \mathrm{s}$ layer and the $7.0 \mathrm{~km} / \mathrm{s}$ layer. On the continental slope, the Research Group OBS line and profile P-7 did not detect a shallow $7 \mathrm{~km} / \mathrm{s}$ layer, but profiles SB-3 and 4 and two-ship profile P-6 show the layer. By analogy with the crustal structure of Northeast Japan, there is a possibility that the $7 \mathrm{~km} / \mathrm{s}$ layer exists in the crust under the continental slope above the descending Pacific plate, but it may be very thin (masked). Alternatively, the least-complex interpretation involving correlation of layers with similar velocity may have little relation to the actual geology.

\section{RELATIONSHIP OF STRUCTURE TO SEISMICITY}

Geological and geophysical studies were concentrated in an E-W-trending corridor near lat. $39^{\circ} \mathrm{N}$ during 1964-69, as one of three transects of the Japanese Islands made under the Upper Mantle Project of Japan. Kitamura and Onuki (1973) have presented a crustal section of Northeast Japan. Figure 5 is a revised version of the section that has been supplemented with the new seismic data described above. Earthquake hypocenters located by seismologists of the Tohoku University of Japan (Hasegawa et al., 1978) are shown in the lower part of Figure 5, where the heavy dashed line represents the seismically derived surface of the descending Pacific plate, which follows at depth the upper seismic belt of the Wadati-Benioff zone of Hasegawa and Umino (1978). Systematic errors in the location of hypocenters due to sparse information on how sound velocity varies with depth probably account for the seismically derived surface being about $3 \mathrm{~km}$ shallower than the actual surface of the descending plate (shown by a light dotted line); hence, no significance is placed on this seeming discrepancy.

A hypothetical convection cell in the aseismic zone under the volcanic arc and solutions of focal mechanism of the earthquakes from Hirono (1978) and Hasegawa

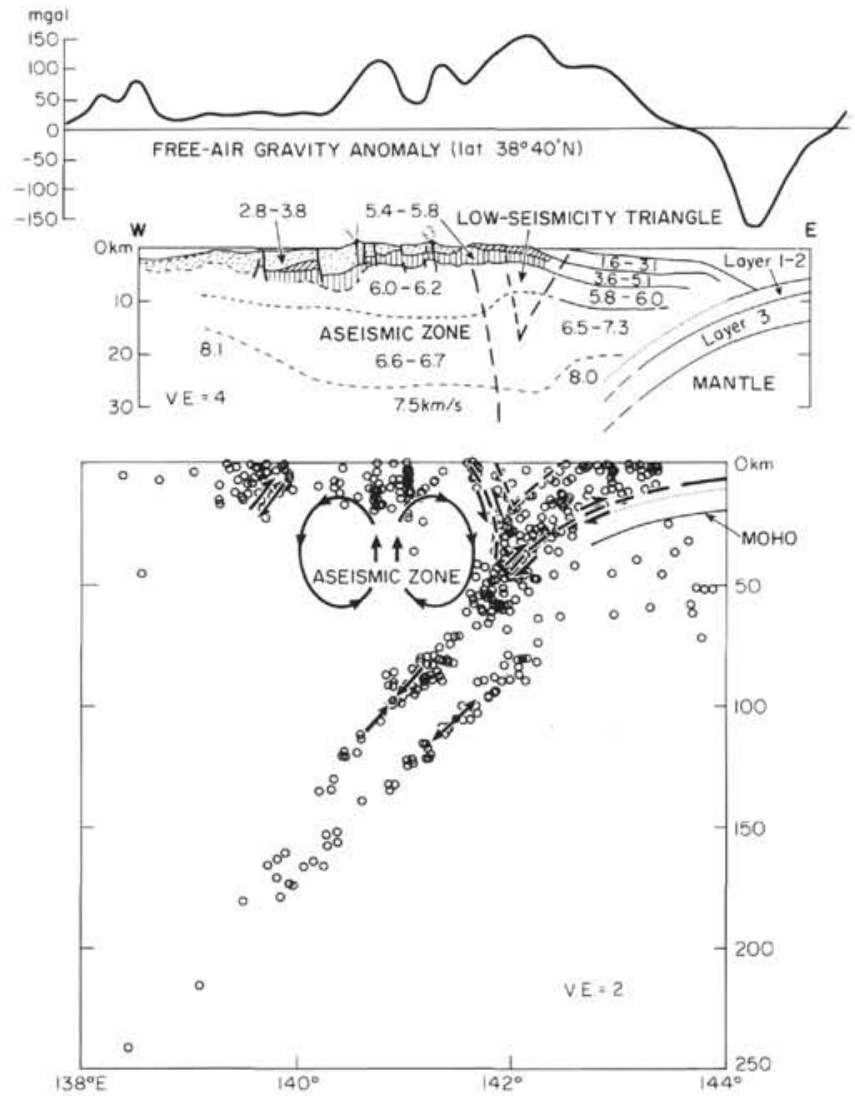

Figure 5. Velocity structure of the Japan arc-trench system along lat. $39^{\circ} \mathrm{N}$ in relation to free-air gravity anomaly (top), and distribution of earthquake hypocenters (bottom). Sources of data are given in the text.

and Umino (1978) are also shown in the lower part of Figure 5. The distribution of hypocenters indicates a seismic zone that dips seaward from the volcanic arc to intersect the landward-dipping Wadati-Benioff zone. The area between the seismic zones has low seismicity. Opposed seismic zones forming a low-seismicity triangle are characteristic of the Kanto district of Japan (Tsumura, 1973) and of other island arc-trench systems (e.g., Aleutian arc, Engdahl, 1977).

\section{DISCUSSION}

It is tempting to speculate that the area between the aseismic zone and the descending Pacific plate is an area of crustal upheaval arising from compressive forces along the opposed seismic zones. However, we know from drilling that the crust has subsided near the trench-slope break since Miocene time. The idea of subsidence of the inner slope of the Japan Trench was advanced by Iijima and Kagami (1969) on the basis of study of rocks dredged near the trench-slope break. A similar conclusion was reached by Murauchi (1971a, b) for the Bonin Trench.

As mentioned earlier, if all the sediments of the lower inner trench slope were scraped off the Pacific plate during the Neogene, they would greatly exceed the 
observed volume in the sedimentary prism. Furthermore, no Pacific plate sediments were found in the core samples from Sites 441 and 434 on the lower inner trench slope. Any hypothesis of the mechanism of plate subduction beneath the Japan Trench must therefore address the problems of sediment removal and overall subsidence of the outer margin where the leading edge of the continental block overrides the oceanic plate.

A conceptual diagram of a possible mechanism of sediment removal in the Japan Trench was presented by Murauchi (1975), as shown in Figure 6. The diagram pertains to the present phase of subduction of the Japan Trench. According to the concept, several faults occur beneath the inner trench slope and are generally parallel to the surface of the descending plate. Parts of the sedimentary prism will be carried down with the descending plate on successively deeper planes of décollement until basal décollement finally occurs between the sediment and the oceanic crust. Dewatering of the sediments is likely to occur at the contact between the continental block and the descending plate. Hence, the water that would be released as the sediments are squeezed could lubricate the slip planes and decouple the overthrusting continental block from the descending plate. As time passes, the slip planes will migrate upward (because the water gradually migrates upward) into the overlying continental material, i.e., the continental block is eroded from the base.

From study of the frequency-magnitude distribution of earthquakes that occur just above the descending Pacific plate, Anderson et al. (1979) conclude that there
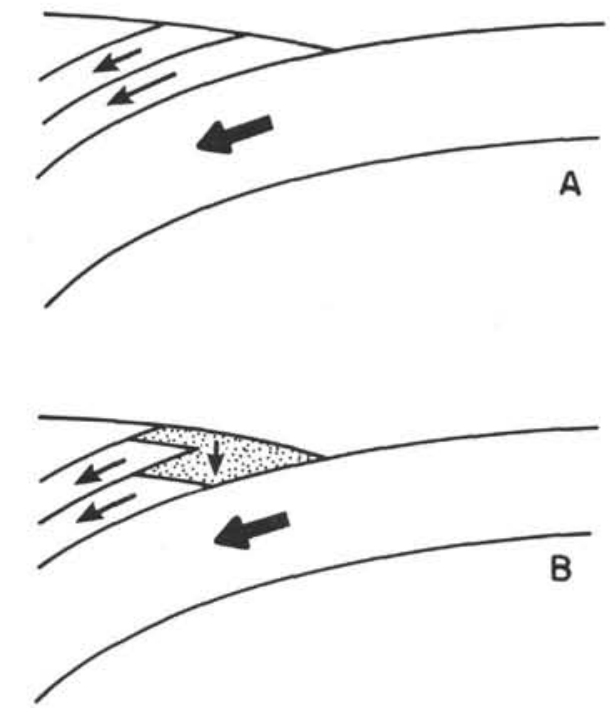

Figure 6. Conceptual diagram of sediment removal in the Japan Trench, modified from Murauchi (1975). A. Several faults are assumed to occur at the base of the continental edge parallel to the surface of the descending ocean plate. B. Sediments transported from the continent and scraped off the descending plate are dragged down by the plate on successively deeper décollement planes. Dewatering of the sediments lubricates the fault planes and thus lowers the shear strength between the plates. is a low-strength zone from the sea bottom to $30 \mathrm{~km}$ depth. It presumably is caused by high pore pressure from free water in the oceanic crust, which lowers the effective stresses. We simply note that the excess pore pressures along the surface of the descending plate may be brought about by the introduction of free water into the sediments, as well as by free water in the ocean crust.

Advance of the Pacific plate against the island-arc mass, or vice versa, will result in uplift of the leading edge of the island-arc mass; however, the dominant motion is subsidence, because of tectonic erosion at its base, as shown diagrammatically in Figure 7 . In this figure, the surface of the descending plate, the water depth at the trench axis, and the wedge shape of the leading edge of the continental block are kept constant. As mentioned above, there is a complex fault zone just above the surface of the descending plate that consists of sediments carried down with the plate and material eroded from the base of the continental block (Figure 7A). The block will subside because of removal of material from its base. Simultaneously, the surface of the descending plate will tend to rise through advancement of the plate. The net effect is to progressively shift the trench axis and thin the continental edge landward (Figure 7B). Between 30 and $60 \mathrm{~km}$ depth, thinning of the continental block will not occur as much as at lesser depth, because this is a zone of higher shear strength, as discovered by Anderson et al. (1979). Therefore, the

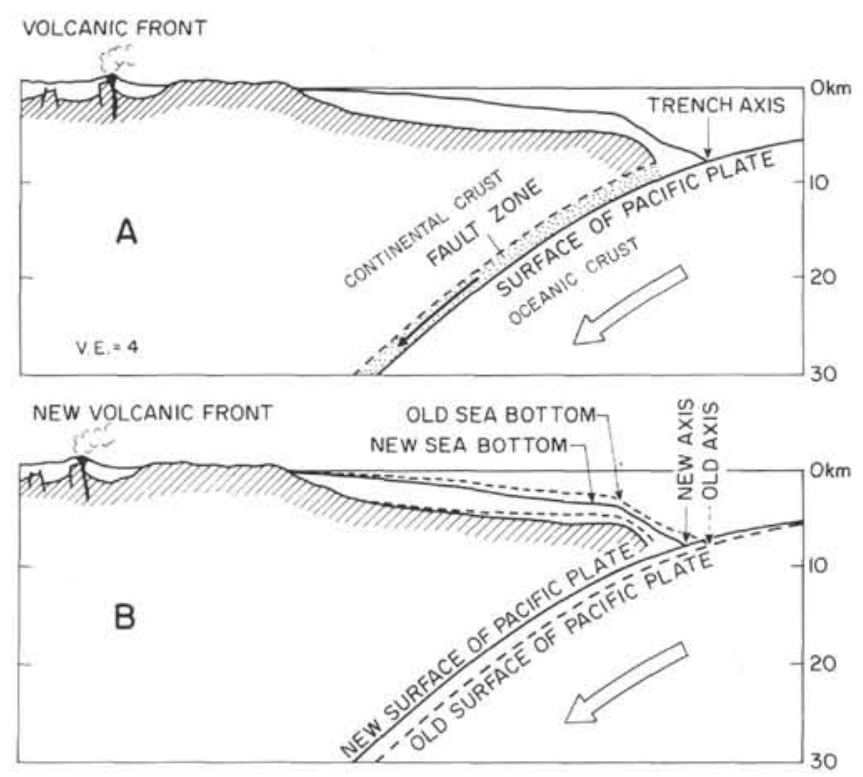

Figure 7. Conceptual diagram of the effect of subduction of ocean crust in the Japan Trench. A. Terrigenous and oceanic sediments are carried down (subducted) with the oceanic plate. The slip planes migrate upward into the continental block, causing erosion at its base. A complex fault zone is thus formed. B. With time the continental edge becomes thinner and subsides, the trench axis is displaced landward, and the Pacific plate advances against the island-arc mass. 
continental block above the Wadati-Benioff zone at 30 to $60 \mathrm{~km}$ depth will be uplifted through advancement of the plates. Uplift of the eastern part of Northeast Japan has been prevalent since Neogene time.

In our view of the subduction mechanism acting on the Japan Trench (and on other trenches), tectonic erosion with subsidence and retreat of the continental edge, rather than sediment accretion and outbuilding, is the dominant process. Sediments are accreted to the margin through uplift (offscraping) of trench sediments, but we believe that most of these sediments are later consumed along with the leading edge of the continental block. Of course, if for some reason the amount of sediment entering the trench greatly exceeds the amount being removed, the net effect will be accretion and displacemerit of the trench axis seaward. This type of trench may be called the "inundation" type. We believe that the Japan Trench is likely a "tectonic erosion type." But far more data, especially from deep drill holes and seismic velocity structure and seismological measurements, will be required before classification of other trenches can be attempted.

\section{ACKNOWLEDGMENTS}

This work was done while the senior author was on leave from Chiba University at Lamont-Doherty Geological Observatory on an L-DGO-sponsored Senior Post-Doctoral Fellowship. We thank R. Houtz, M. Langseth, M. Talwani, and $\mathrm{C}$. Windisch for critically reading the manuscript.

\section{REFERENCES}

Anderson, R. N., Hasegawa, A., and Takagi, A., 1979. The frequency magnitude distribution in the double-planed seismic zone beneath Tohoku, Japan. Eos, 60, 312.

Engdahl, E. R., 1977. Seismicity and plate subduction in the central Aleutians. In Talwani, M., and Pittman, W. C., III (Eds.), Island Arcs, Deep Sea Trenches and Back-Arc Basins: Washington (Am. Geophys. Union), pp. 356-371.

Grow, J. A., 1973. Crustal and upper mantle structure of the Central Aleutian Arc. Geol. Soc. Am. Bull., 84, 2169-2191.

Hasegawa, A., and Umino, N., 1978. Focal depth distribution of micro-earthquakes and focal mechanism in the northeastern Japan arc. Abs. Seismol. Soc. Japan, 1978-1 A-38. [In Japanese]

Hasegawa, A., Umino, N., and Takagi, A., 1978. Doubleplaned structure of the deep seismic zone in the northeastern Japan arc. Tectonophysics, 47, 43-58.

Hirono, T., 1978. A countercurrent accompanying the descending Pacific lithosphere. Zisin, 31, 191-211. [In Japanese with English abstract]

Hotta, H., 1970. A crustal section across the Izu-Ogasawara arc and trench. J. Phys. Earth, 18, 125-141.

Iijima, A., and Kagami, H., 1969. Cainozoic tectonic development of the continental slope, northeast of Japan. J. Geol.
Soc. Japan, 67, 561-577. [In Japanese with English abstract]

Kitamura, N., and Onuki, Y., 1973. Geological and crustal sections of the A-Zone, Northeast Japan. In The Crust and Upper Mantle of the Japanese Area (Vol. 2): Tokyo (Univ. of Tokyo), pp. 38-60.

Kuhm, L. D., Schweller, W. J., and Masias, A., 1977. A preliminary analysis of the subduction processes along the Andean continental margin, $6^{\circ}$ to $45^{\circ} \mathrm{S}$. In Talwani, M., and Pittman, W. C., III (Eds.), Island Arcs, Deep Sea Trenches and Back-Arc Basins: Washington (Am. Geophys. Union) p. 285-301.

Ludwig, W. J., Ewing, J. 1., Ewing, M., Murauchi, S., Den, N., Asano, S., Hotta, H., Hayakawa, M., Asanuma, T., Ichikawa, K., and Noguchi, 1., 1966. Sediments and structure of the Japan Trench. J. Geophys. Res., 71, 2121-2137.

Matsuzaki, T., 1959. Magnetic anomaly over and around the Japan Trench of Sanriku and the Yamato Bank in the Japan Sea. Rept. Hydro. Res., vol. 1, 1-10. [In Japanese]

Murauchi, S., 1971a. The renewal of island arcs and the tectonics of marginal seas. Proc. Joint Oceanogr. Assembly, Tokyo, 1970, 303-305.

$1971 \mathrm{~b}$. The renewal of island arcs and the tectonics of marginal seas. In Island Arc and Marginal Sea: (Tokai University Press), p. 39-56. [In Japanese with English abstract]

1975. Crustal structure in the Philippine Sea. Mar. Sci., 7, 537-542. [In Japanese]

Murauchi, S., Asanuma, T., and Ishii, H., 1973. Geophysical studies on the sea around Hokkaido. Mem. Natl. Sci. Museum, 6, 163-182.

Murauchi, S., Asanuma, T., Kinoshita, H., Nakatani, H., Mitamura, M., Sakai, M., Tokumaru, M., and Hayashi, K., 1979. Sediments and structure of subduction zone off Northeast Japan. Eos, 60, 315.

Murauchi, S., Asanuma, T., Taguchi, H., Kinoshita, H., Yokoyama, I., Nakatani, H., Yokota, T., and Tanaka, K., 1978. Crustal structure of the island-arc slope and the trench off Sanriku and mechanism of subduction. Mar. Sci., 10, 207-214. [In Japanese]

Nasu, N., Tomoda, Y., Kobayashi, K., Kagami, H., Uyeda, S., Nagumo, S., Kushiro, I., Ozima, M., Nakazawa, K., Takayanagi, T., Okada, H., Murauchi, S., Ishiwada, Y., and Ishii, Y., 1979. Multichannel Seismic Reflection Data Across the Japan Trench. IPOD-Japan Basic Data Series, No. 3.

Scientific Staff of IPOD-Leg 57, 1978. Japan trench transected. Geotimes, 23 (4), 16-21.

Tsumura, K., 1973. Microearthquake activity in the Kanto district. In Publications for the 50th Anniversary of the Great Kanto Earthquake, 1923, pp. 67-87. [In Japanese]

Westbrook, G. K., 1975. The structure of the crust and upper mantle in the region of Barbados and the Lesser Antilles. Geophys. J. Roy. Astronom. Soc., 43, 201-242.

Yoshii, T., and Asano, S., 1972. Time-term analysis of explosion seismic data. J. Phys. Earth, 20, 47-58. 